Article

\title{
Interannual and Intraseasonal Variations of the Onset and Demise of the Pre-Wet Season and the Wet Season in the Northern Northeast Brazil
}

\author{
Francisco das Chagas Vasconcelos Junior ${ }^{1}$ iD, Charles Jones ${ }^{2}$, Adilson Wagner Gandu ${ }^{3}$ \\ ${ }^{1}$ Fundação Cearense de Meteorologia e Recursos Hídricos, Fortaleza, CE, Brazil. \\ ${ }^{2}$ Department of Geography and Earth Research Institute, University of California Santa \\ Barbara, Santa Barbara, California, USA. \\ ${ }^{3}$ Instituto de Ciências do Mar, Universidade Federal do Ceará, Fortaleza, CE, Brazil.
}

Received in February 10, 2018 - Accepted in April 19, 2018

\begin{abstract}
The Northern Northeast Brazil (NNB) has two rainy periods, namely Pre-Wet Season (PWS) and Wet Season (WES), which are usually treated as one system. The precipitation pattern on NNB is influenced by sea surface temperature (SST) anomalies in the Atlantic and Pacific Ocean on interannual timescales particularly by the Interhemispheric Gradient of SST anomalies (IGS) and El Niño Southern Oscillation (ENSO). On intraseasonal time scales, the MJO is especially important. This study investigates the variability of the PWS/WES. The PWS is largely associated with the development of the South America Monsoon System and South Atlantic Convergence Zone (SAMS/SACZ); the onset is depicted by incursion of the SAMS/SACZ northward. Anomalous atmospheric cyclonic circulation over the southeastern Brazil along with easterlies over the northern Tropical Atlantic marks the early onset of the PWS, while easterlies over the southern Tropical Atlantic are related to late onset episodes. The demise of the PWS is significantly associated with propagation of the MJO, specifically during phases 4-5 of the MJO lifecycle. A Rossby wave train in 200-hPa geopotential height with positive anomalies over central-southern Brazil is depicted during transition between PWS and WES.
\end{abstract}

Keywords: pre wet season, wet season, Northeast Brazil, MJO.

\section{Variações Interanuais e Intrasazonais do Início e do Fim da Pré-Estação Chuvosa e da Estação Chuvosa no Norte do Nordeste do Brasil}

\begin{abstract}
Resumo
O norte do Nordeste do Brasil (NNB) têm dois períodos úmidos, a pré-estação chuvosa (PESC) e a estação chuvosa (EST), as quais geralmente são tratadas como uma. O regime de chuva sobre o NNB é influenciado pelas anomalias de Temperatura da Superfície do Mar (TSM) nos Oceanos Atlântico e Pacífico em escalas interanuais particularmente pelo gradiente inter-hemisférico de anomalia de TSM (IGS) e o El Nino Oscilação Sul. Na escala intrasazonal, a Oscilação de Madden Julian (OMJ) é importante. Este estudo investiga a variabilidade da PESC e EST. A PESC é associada com o desenvolvimento do sistema de monção da América do Sul e da Zona de Convergência do Atlântico Sul (SAMS/SACZ); o início é representado pela incursão do SAMS/SACZ para norte. Circulação atmosférica ciclônicas anômalas sobre o sudeste brasileiro juntamente com anomalias de leste sobre Atlântico Tropical Norte marcam inícios antecipados da PESC, enquanto anomalias de leste sobre se posicionam sobre o Atlântico Tropical Sul são relacionados com episódios de início tardio. O final da PESC está intimamente associado com propagação da OMJ, especialmente durante as fases 4-5 de seu ciclo de vida. Um trem de ondas de Rossby no campo de altura geopotencial em $200 \mathrm{hPa}$ é observado, com anomalias positivas sobre centro-sudeste do Brasil retratando sua ocorrência durante a fase de transição entre PESC e EST.
\end{abstract}

Palavras-chave: pré estação chuvosa, estação chuvosa, Nordeste do Brasil, OMJ.

Corresponding author: Francisco das Chagas Vasconcelos Junior, juniorphy@gmail.com, francisco.vasconcelos@funceme.br. 


\section{Introduction}

The Northern Northeast Brazil (hereafter NNB) has complex climatic characteristics with short Pre-Wet Seasons (PWS) (Brito and Nobre, 1991) and Wet Seasons (WES) (Moura and Shukla, 1981; Hastenrath and Greichar, 1993). Previous studies indicated that the PWS occurs climatologically between October and January (Brito and Nobre, 1991; Alves et al., 1993; Moura and Hastenrath, 2004) and upper tropospheric cyclonic vortexes (Kousky and Gan, 1981) and equatorward intrusions of cold fronts (Kousky, 1979) are the main precipitating systems. The WES occurs from February to May and is strongly associated with the southward position of the Intertropical Convergence Zone (ITCZ) (Uvo and Nobre, 1989). Although previous studies have provided important elements to understand the precipitation variability over the NNB (Moura and Hastenrath, 2004; Sun et al., 2005; and references therein), our understanding of the mechanisms controlling the onset and demise of the PWS and WES is still limited.

In fact, onset and duration of the rainy seasons is essential information to start planting and time to harvest, public heathy, hydric management, and potentially important to hydropower generation (Coelho et al., 2017). Rainfed agriculture (depend on rainfall only) and financial income from crops are the bases of socio-economical activities in rural regions in NNB (Alves et al., 2010), which the decision of seed-releasing affects the vulnerability of the region and justifying even more the relevance of understanding the characteristics of the onset and demise of the rainy periods.

Kousky (1988) determined the climatological onset and demise of the rainy season over the NNB to be in late December last about 55 days inland and about 125 days over coastal areas. Rauscher et al. (2007) used daily gridded precipitation from gauge observations and found the mean rainy season over the Northeast of Brazil (2S-13S; $45 \mathrm{~W}-37 \mathrm{~W}$ ) to start in mid-December and last about 140 days. Although they did not investigate the PWS, they showed the onset of the rainy period over the Northeast to be in early December. These results seem to suggest that the PWS is part of the WES.

Previous studies have also shown that the interannual precipitation variability during the PWS and the WES is driven by sea surface temperature (SST) anomalies on the tropical Pacific and Atlantic Oceans (Brito and Nobre, 1991; Hastenrath and Heller, 1977; Alves et al., 1993; Uvo et al., 1998). Alves et al. (1993) found that dry (wet) PWS occur during warm (cold) El Niño/Southern Oscillation (ENSO) phases. Negative correlations between sea surface temperature anomalies over the central-eastern Pacific and rainfall anomalies over the Northeast Brazil were reported by Uvo et al. (1998). Brito and Nobre (1991) showed negative correlations between precipitation anomalies and Interhemisferic Gradient of SST anomalies (IGS). IGS is an asymmetrical distribution of the SST anomalies across the equatorial tropical Atlantic (Servain, 1991; Chiang and Vimont, 2004). In fact, early studies have clearly connected the SST variability over the tropical Atlantic Tropical to the seasonal climate over the NNB, whereby positive (negative) IGS is related to an anomalous northward (southward) position of the ITCZ and reduced (enhanced) rainfall anomalies (Hastenrath and Heller, 1977; Moura and Shukla, 1981; Nobre and Shukla, 1996).

Some studies have also pointed out that precipitation variability in South America (Taschetto and Wainer, 2008) and the NNB in particular (Kayano and Andreoli, 2004; Andreoli and Kayano, 2007) can be explained by SST anomaly patterns in the South Atlantic. Bombardi et al. (2014) showed associations between the South Atlantic Dipole Index and precipitation anomalies in the South America Monsoon System (SAMS).

In addition, intraseasonal disturbances also influence the climate of South America (e.g., Jones and Carvalho, 2002 ) and of the NNB in particular (Kousky and Kayano, 1994; Jones et al., 2004; Souza and Ambrizzi, 2006; Liebmann et al., 2011; Valadão et al., 2015; Shimizu and Ambrizzi, 2016). Souza and Ambrizzi (2006) showed that the Madden-Julian Oscillation (MJO) (Madden and Julian, 1994) influences the precipitation variability over the eastern Amazon and NNB sector, playing an important role in modulating the regional rainfall. Carvalho et al. (2004) found significant relationships between the MJO, extreme precipitation events and intense South Atlantic Convergence Zone (SACZ) activity.

The main goal of this study is to investigate the onsets and demises, especially the transitions from PWS to WES on intraseasonal-to-interannual time scales. The following questions are addressed: 1) What are the difference between the PWS and the WES? 2) What are the atmospheric circulation patterns associated with early/late onset/demise of the PWS and the WES? 3) Because on the intraseasonal characteristics of the transitions, does the MJO have a significant role at the onset and demise of the PWS and the WES on the NNB? The paper is organized as follows: Section 2 describes the data and methods utilized; Section 3 presents the results and discussion; Summary and conclusions are presented in the Section 4.

\section{Data and Methods}

Non-overlapping pentad was computed from daily gridded precipitation (Liebmann and Allured, 2005) and calculated the spatial average on the NNB region (Fig. 1) to investigate the temporal variability of the onsets and demises of the PWS and WES. To analyze the importance of the MJO, the index described in Jones and Carvalho (2012) is used. To analyze changes in the large/regional scale atmospheric circulation associated with early/late onsets/demises of the PWS and the WES, pentads of the zonal and meridional wind components at $200-\mathrm{hPa}$ and $850-\mathrm{hPa}$, di- 


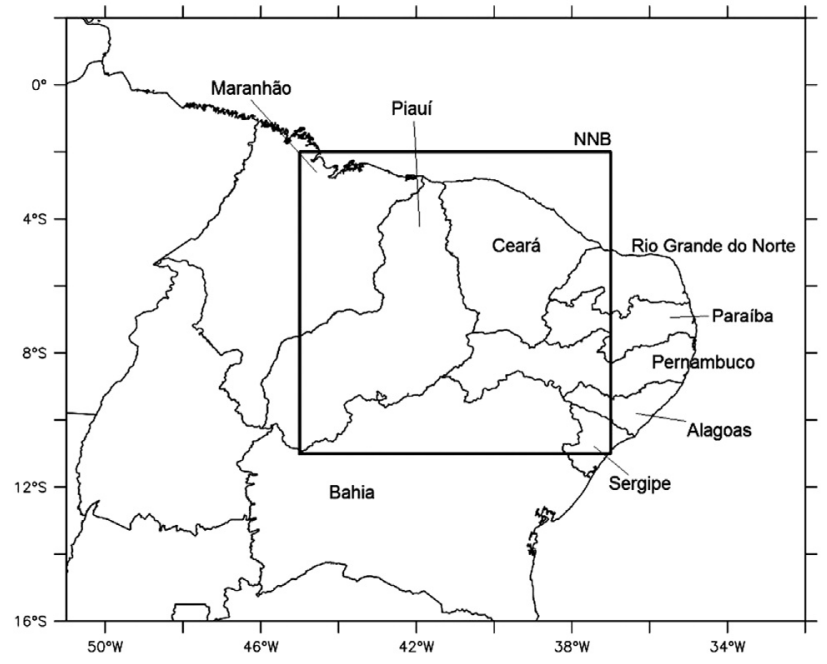

Figure 1 - Northeast region of Brazil. The black square depicts the study area, Northern Northeast Brazil (NNB).

vergence of integrated moisture flux (DIV) and geopotential high at $200-\mathrm{hPa}$ (H200) from the Era-Interim reanalysis are used (1979-2010). Anomalies are defined here as departure from the mean seasonal cycle.

The method to determine the onset and demise of the PWS and the WES is based on Liebmann and Marengo (2001) and adapted by Bombardi and Carvalho (2009). The wet season onset and demise is based on the running sum $(\mathrm{S})$ of the pentad precipitation deviation from the climatological annual mean precipitation. The sum starts always at the dry season. The onset of the PWS (WES) is defined when $d S / d t$ becomes positive for at least three consecutive (five) pentads. Likewise, the demise of the PWS (WES) is defined when $d S / d t$ becomes negative for at least two (four) consecutive pentads. The separation between the PWS and the WES is ensured by an additional criterion of at least 2 pentads from the PWS demise to the WES onset. The classification of onsets/demises of the PWS and the WES is applied to the time series of rainfall spatially averaged over the NNB.

Intrinsic differences between PWS and WES are investigated. The analysis focuses on dynamical atmospheric characteristics and water vapor transport on regional scale by using composites of atmospheric flow at upper and low levels, and water vapor fluxrelated fields. Anomalies in the onsets/demises of PWS (WES) are calculated using the climatological mean and standard deviation of the onset and the demise dates. An early (late) onset/demise is defined when the onset/demise occurs before (after) the climatological mean onset/demise date minus (plus) 0.75 standard deviation of the onset/demise dates. Composites during early/late onsets/demises are shown to characterize the lower and the upper tropospheric circulation.

\section{Results and Discussion}

\subsection{Mean characteristics of the PWS and WES}

The interannual variability of the onset and demise of the PWS (top) and the WES (bottom) are depicted in Fig. 2. The mean onset and demise of the PWS are at December 12 th and at January 25 th, respectively, indicating mean duration of about 10 pentads. The climatological WES shows onset during February 09th and demise at May 12th, resulting in a mean duration of about 20 pentads. This result is consistent with Rauscher et al. (2005) and provides more details about the timing of the PWS and the WES. The remarkable interannual variability of the onset/demise of the WES exhibits periods between 4-8 years and it is known to be associated with ENSO (Kane, 1992, 1997).

In order to understand the intrinsic difference between the PWS and WES, we analyze the mean characteristics of the large-scale atmospheric circulation (Figs 3-6). During the PWS, the upper level circulation over the South America and South Atlantic Ocean is characterized by an anticyclone over the Bolivian Plateau (Bolivian High) and the Northeast low over Tropical South Atlantic (Fig. 3). These features are associated with the intense convective heating over the core of the SAMS (Lenters and Cook, 1997; Zhou and Lau, 1998), yielding favorable rainfall conditions over the NNB when associated with SACZ (Kousky and Gan, 1981). At lower-levels, the deviation of the easterlies on the tropical region over the continent transports water vapor from the Amazon and Tropical Atlantic to southeastern South America (Fig. 4), which is consistent with Chaves and Cavalcanti (2001) and Raia and Cavalcanti (2008). They pointed out that the location of the SACZ over southern Northeast Brazil is controlled by moist transport from Amazon and displacement of South Atlantic anticyclonic eastward. Fluctuations on these features define the precipitation patterns during the PWS on the NNB. From the PWS to the WES the anticyclonic circulation over Tropical South Atlantic in the upper-levels (Fig. 5) indicates the weakening of the Northeast low and over southeastern Brazil in lower-levels (Fig. 6), a "break" phase in the SAMS.

The PWS is not defined on three rainy periods $(1984 / 1985,2003 / 2004$ and 2006/2007) by using the aforementioned method. Analyzing the composite of the integrated moisture flux anomaly during the months from November to February, it is possible to explain the absence of the PWS during those years. Easterly flux anomaly over Central-Western Brazil and an anticyclonic flow anomaly on southeastern South America during November-February (Figs. 7a-d) are patterns similar to findings by Jones and Carvalho (2002) and Carvalho et al. (2004), which indicates inactive phases of the SAMS and the SACZ. The lack of SACZ and monsoon activity indicates disfavoring conditions to development of the PWS, because the PWS rainfall is provided by precipitating systems mainly associated 
a)

PWS

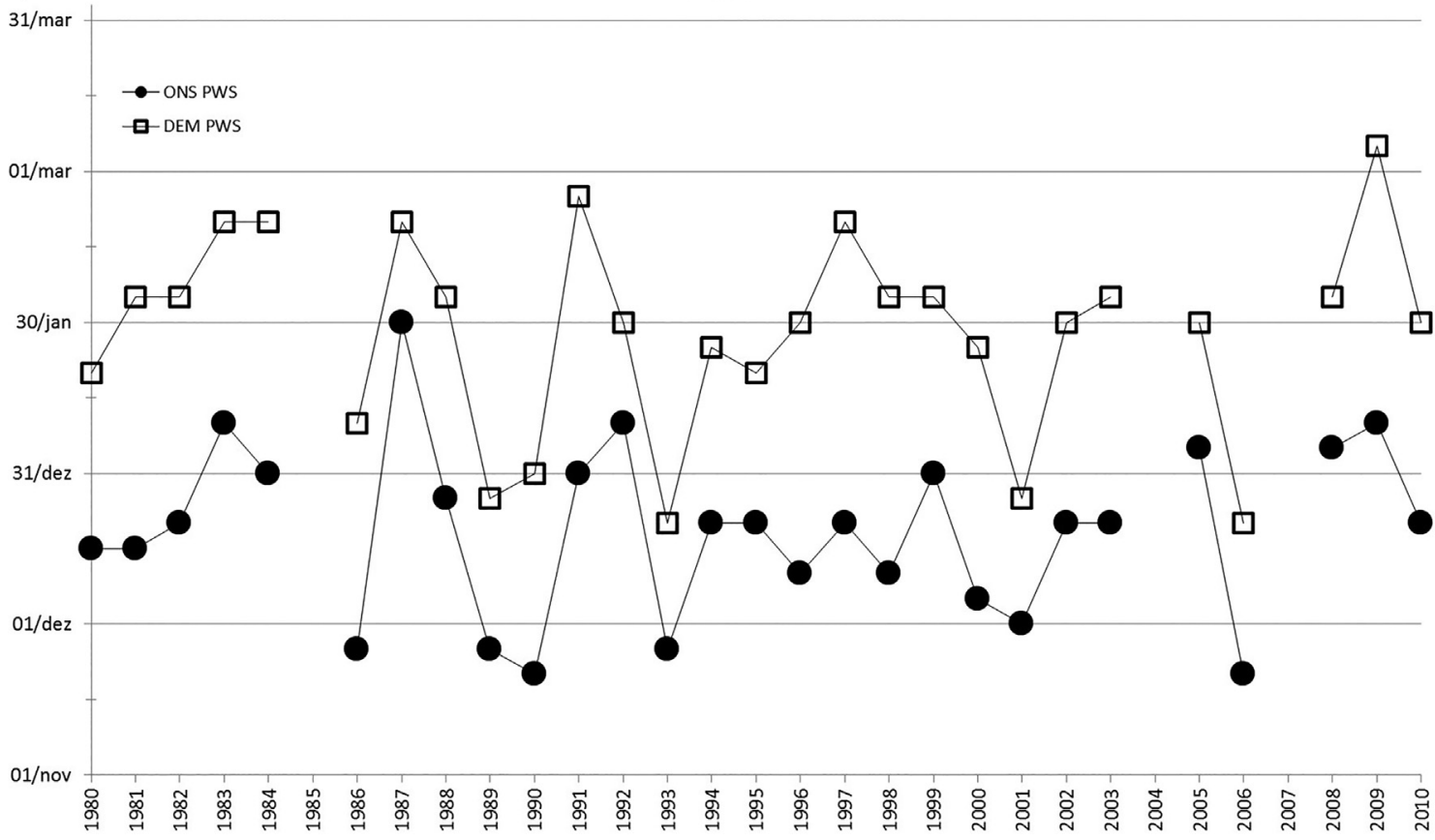

b)

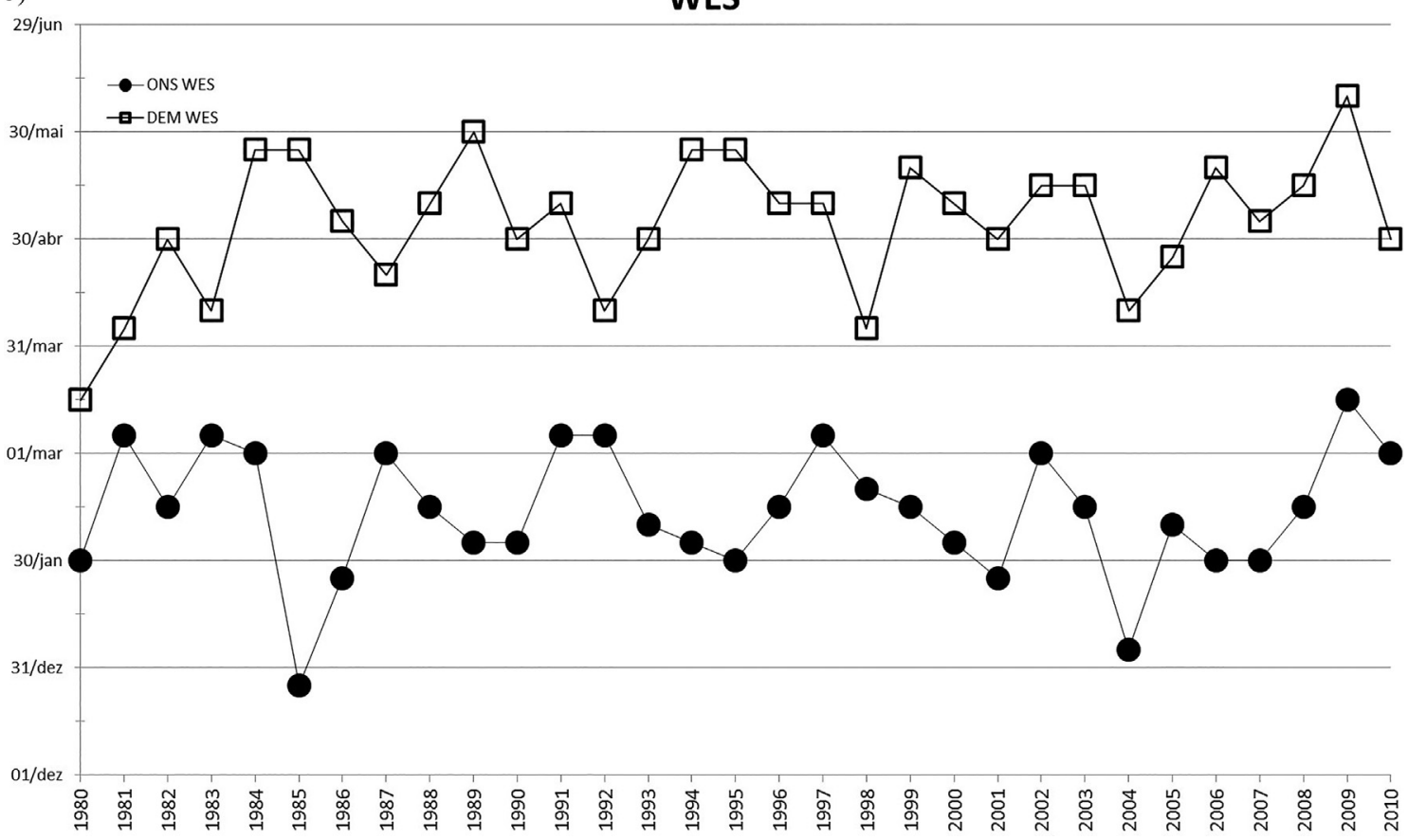

Figure 2 - Interannual variability of the onset and demise of the PWS (top) and the WES (bottom).

with frontal system, for example, upper tropospheric cyclonic vortex (Gan and Kousy, 1981; Brito and Nobre, 1991). These analyses indicate the link between the PWS and summer rainfall systems over South America.

Figure 8 shows the lag composite analysis of the pentad mean precipitation from GPCP during the onset of the PWS. The SAMS/SACZ activity precedes the onset of the PWS, as depicted in the Fig. 8 (top left and right). The propagating precipitation pattern on southeastern Brazil moves towards the NNB and the high precipitation covers the Central-West Region of Brazil at the onset of the PWS (Fig. 8 bottom). An interesting feature is related to the weakening of the ITCZ over the Tropical Atlantic through the development of SAMS and then SACZ over South America, like a seesaw with a submonthly convective variability pattern. This kind of relationship between ITCZ and SACZ agrees with Garcia and Kayano (2010, 2011). 


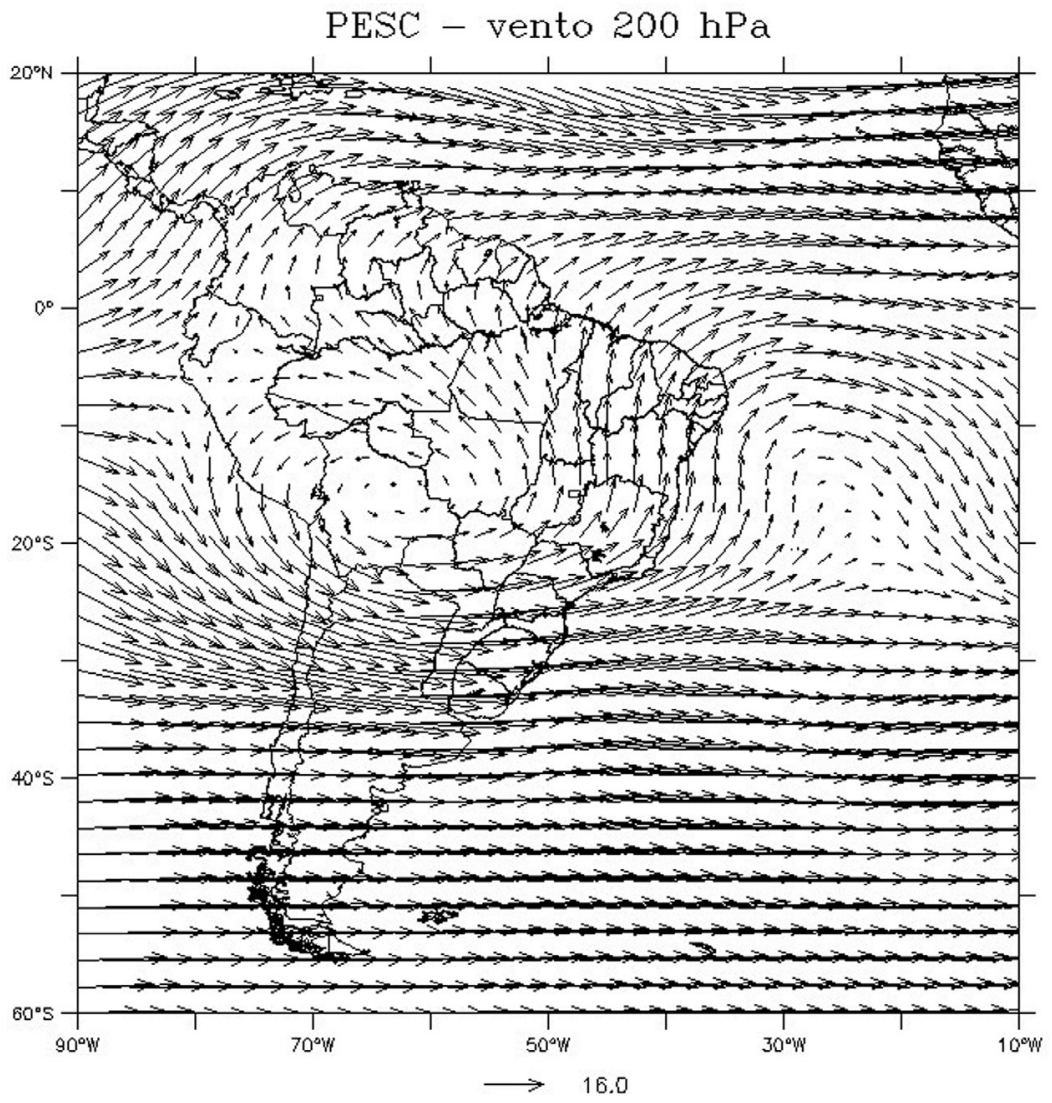

Figure 3 - Mean wind (m/s) 200-hPa during the PWS.

PESC - vento $850 \mathrm{hPa}$

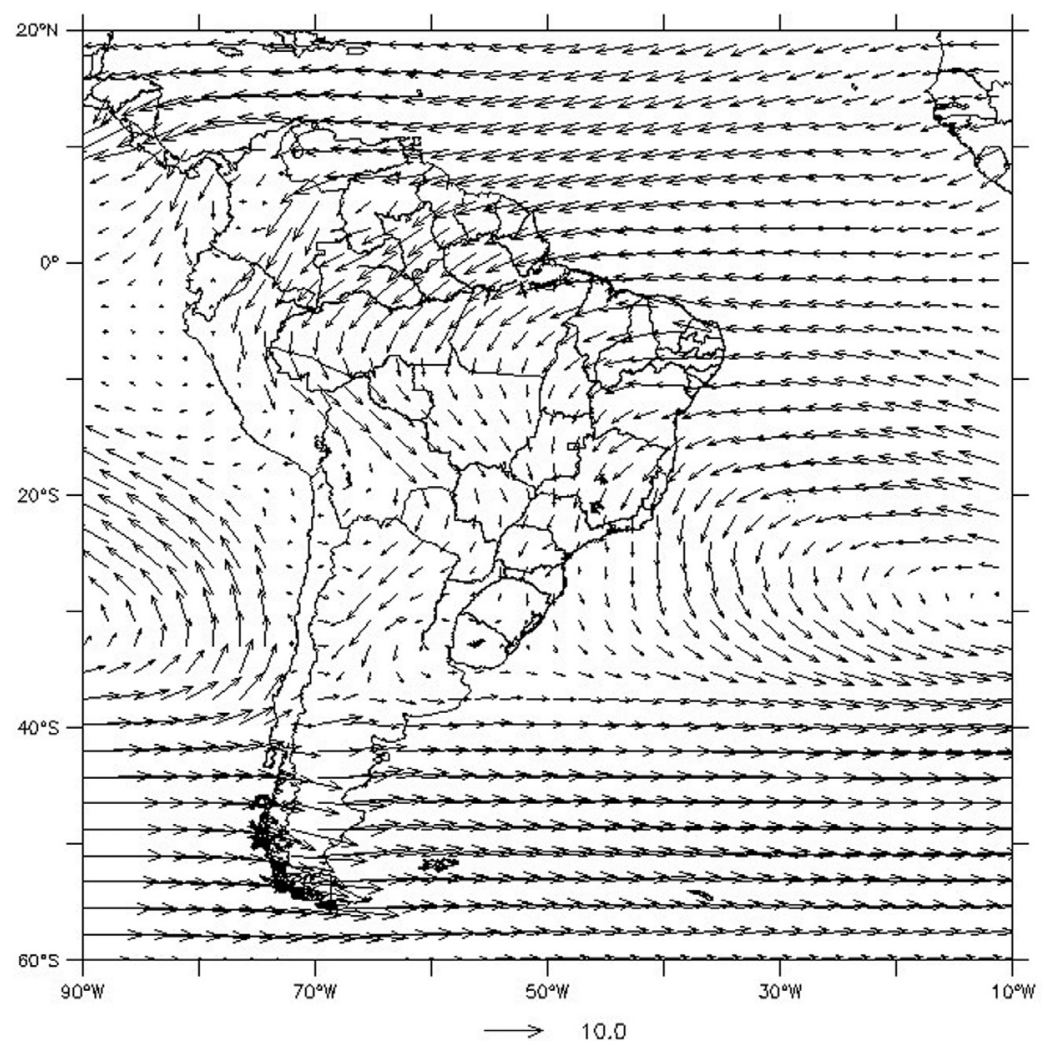

Figure 4 - As Figure 3 except that for level at 850-hPa. 


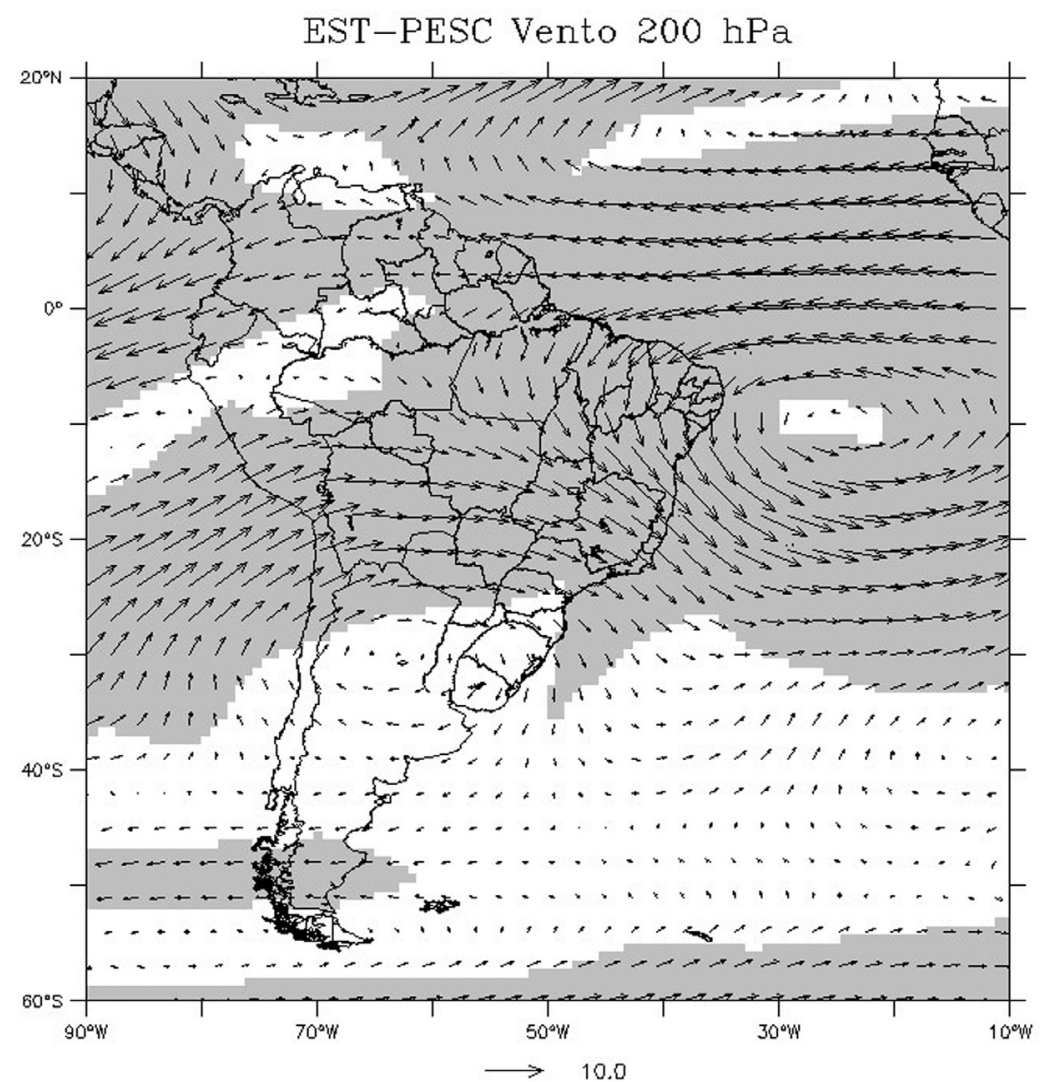

Figure 5 - Mean wind (m/s) at 200-hPa during the WES minus the PWS. Gray regions are statistically significant at $5 \%$ for test of difference between means.

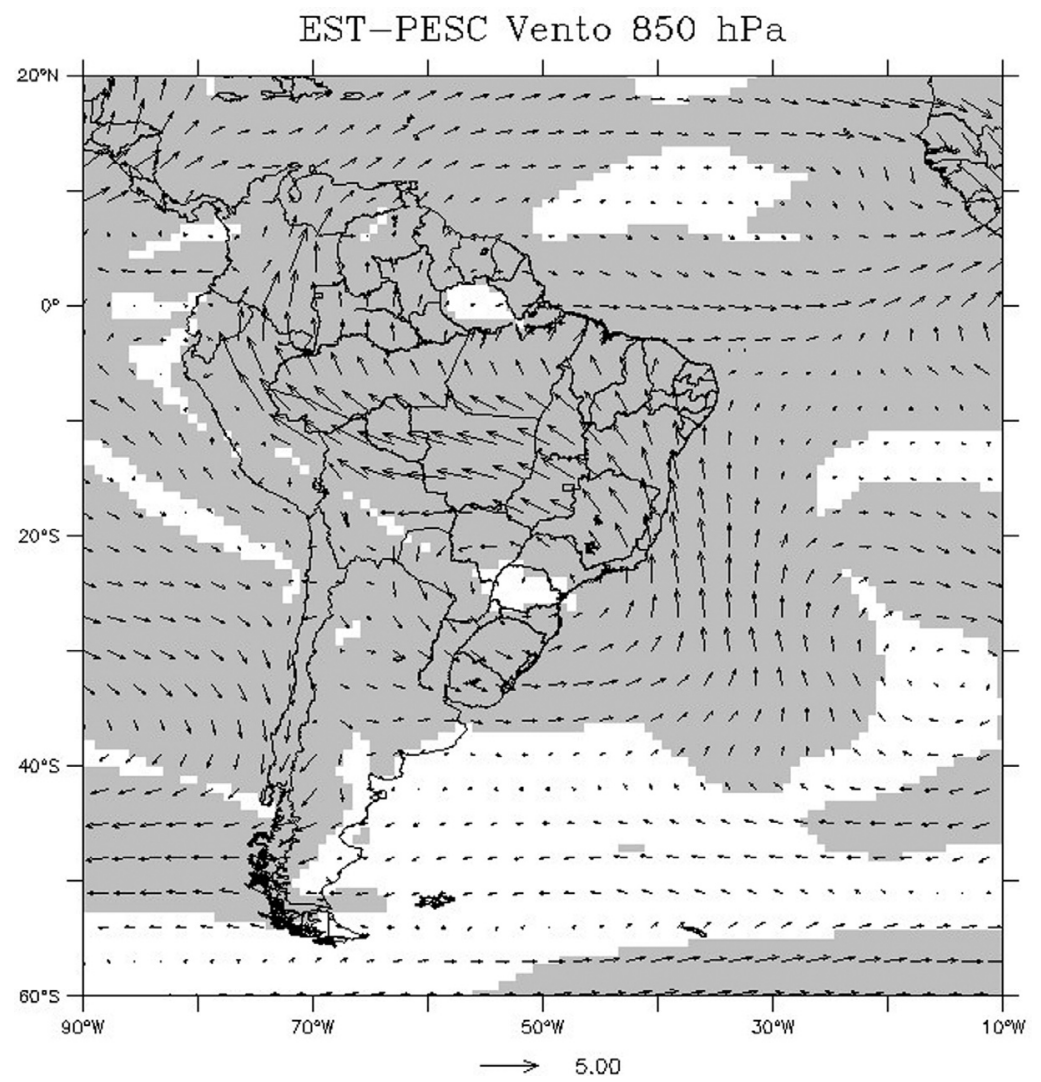

Figure 6 - As Figure 5 except that for the level 850-hPa. 

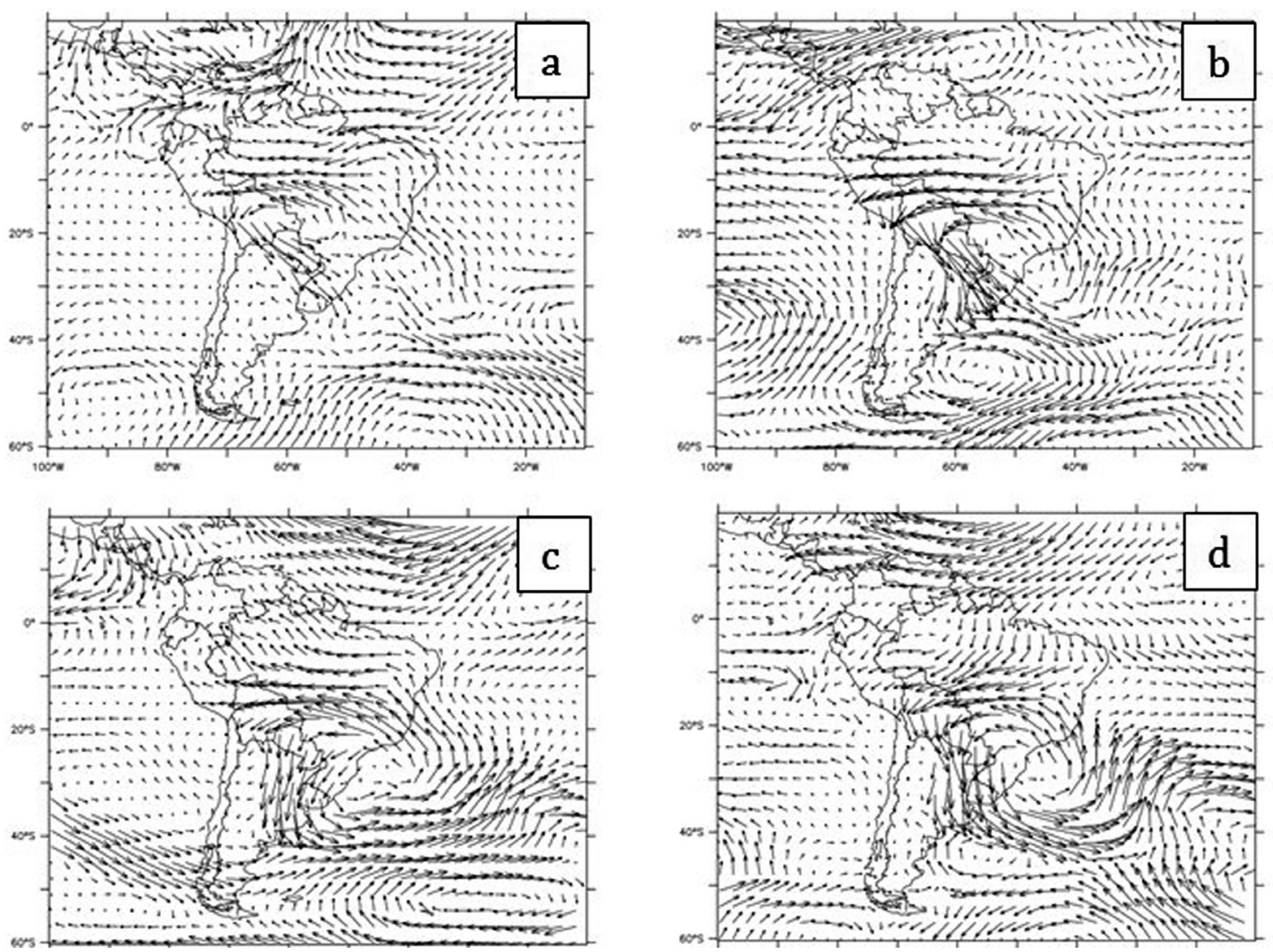

Figure 7 - Composite of monhtly integrated moisture flux anomaly (kg m-1 s-1) for a) November, b) December, c) January and d) February during no PWS (1984/1985, 2003/2004 and 2006/2007).
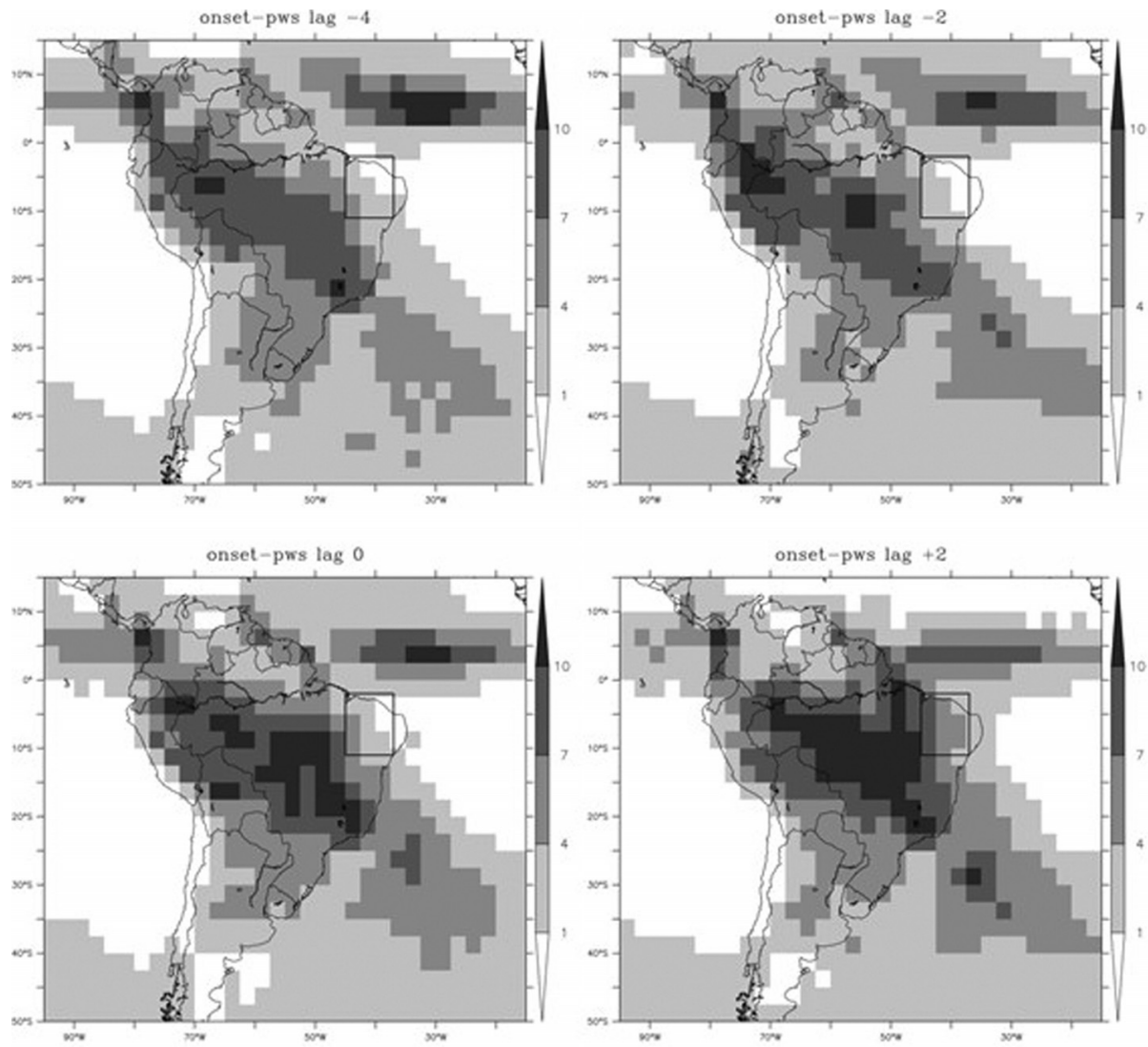

Figure 8 - Lag composite of pentad precipitation from GPCP in the onset of the PWS. Lag -4. lag -2, lag 0 and lag +2 in top left, top right, bottom left and bottom right, respectively. 


\subsection{Composites of early/late onset/demise of the PWS and WES}

Composites of atmospheric circulation during early/late onset/demise of the PWS and the WES indicate anomalous behavior over the Atlantic Ocean and the South Atlantic. These composites were computed with pentads of wind at 200 and $850-\mathrm{hPa}$ from the anomalous episodes of the onset/demise. Anomalous easterlies at 850 -hPa over the Tropical South Atlantic indicate both early and late onsets of the PWS (Figs. 9a and 9b, respectively), but the magnitude of the anomaly in early episodes, it seems to be weaker than in late episodes. Furthermore, an anomalous cyclonic circulation over the Southeastern Brazil/Southwestern South Atlantic in early onset episodes is also observed; this pattern is similar to the one found by Carvalho et al. (2004) for continental SACZ events. This result supports our hypothesis that the incursion of SAMS/SACZ northward has significant influence on the PWS onset. In late onset episodes of the PWS, the pattern is not clear, but the intense trade winds increase moisture transport (not shown) to equatorial South America and the center of the continent, indicating anomalous moisture flux divergence on NNB even at the onset of the PWS (not shown).

In early demise episodes of the PWS (Fig. 9c), easterlies anomalies over northern South America favor the weakening or a break phase of the SAMS (Jones and Carvalho, 2002; Silva and Carvalho, 2007). In addition, anomalous westerlies over the central-western Atlantic Ocean a)

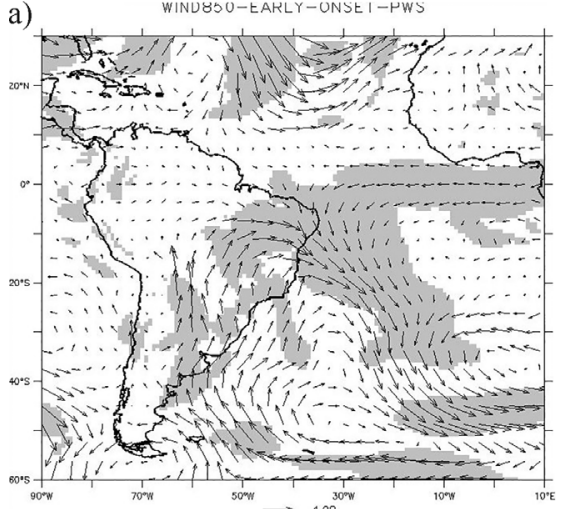

d)

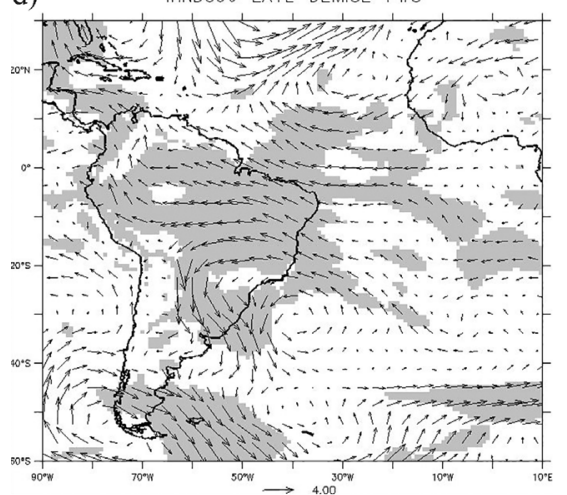

b)

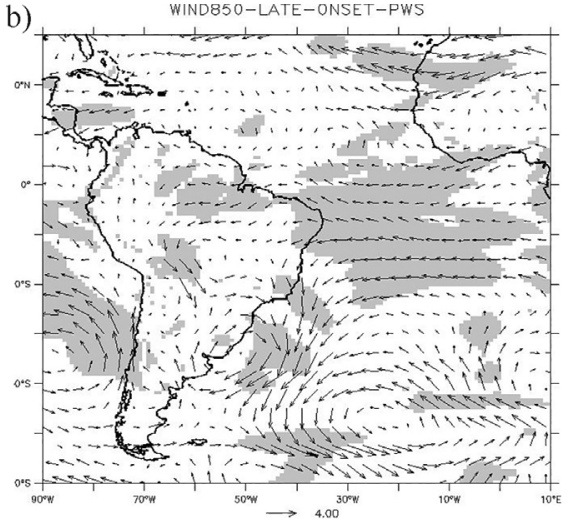

e)

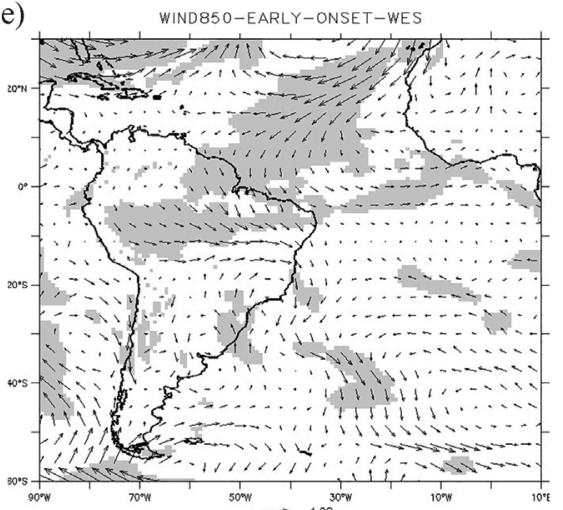

c)
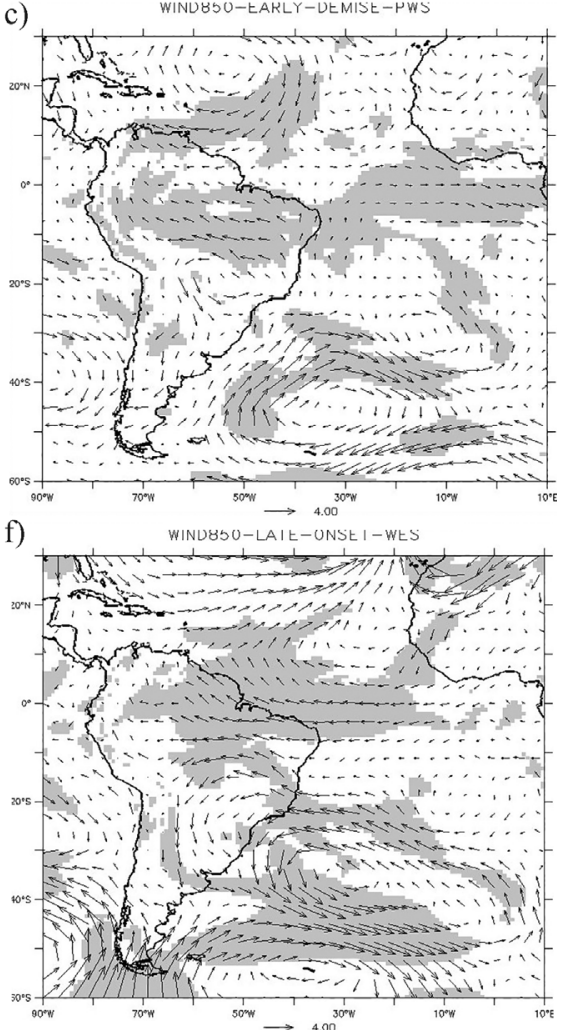

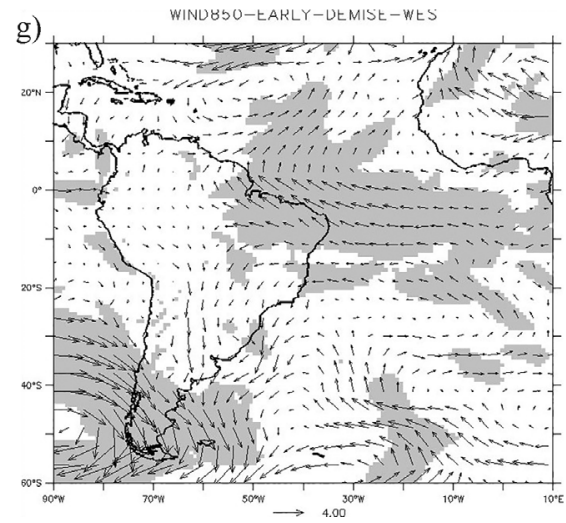

h)

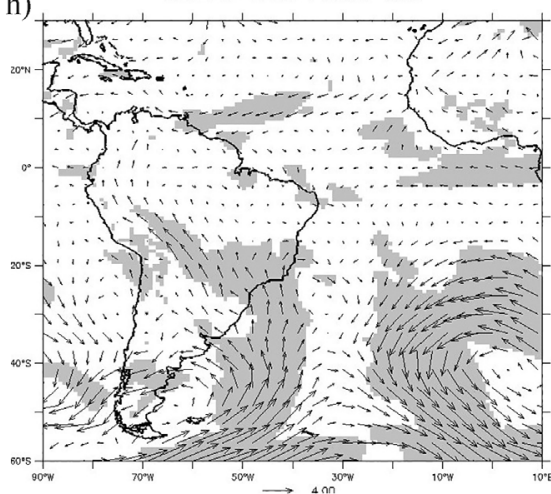

Figure 9 - Composites of wind at $850-\mathrm{hPa}(\mathrm{m} / \mathrm{s})$ for episodes of a) early onset, b) late onset, c) early demise and d) late demise of the PWS, e) early onset and f) late onset, g) early and h) late demise of the WES early onset. Gray regions are statistically significant at $5 \%$. 
can indicate anomalous moisture divergence on the NNB (not shown). In the late demise (Fig. 9d), easterlies over northern South America/eastern Tropical Atlantic occur with an anticyclonic anomaly over southeastern South America. This configuration characterizes the demise of the PWS, although the strengthening of the trade winds supply moisture for the interior of the continent and could explain the delay of the demise of the PWS.

In early onset episodes of the WES (Fig. 9e), the anomalous circulation pattern over the Tropical North Atlantic is opposite from the events of late onset (Fig. 9f). North (south) wind anomalies over the Tropical North Atlantic shifts the ITCZ southward (northward) from its climatological position (Durand et al., 2005); this displacement favors (disfavors) rainfall over NNB. Easterlies over the Tropical South Atlantic are found in early demise episodes of the WES (Fig. 9g), besides anomalous wind from the south causes unfavorable conditions to rainfall in the NNB and explain the premature demise. On the other hand, late demise episodes occur with a shift of the South Atlantic High to southeast north wind anomaly on Tropical North Atlantic and anomalous wind from the south on southeastern Brazil/southwestern South Atlantic (Fig. 9h). Possible connections with IGS over the NNB precipitation are corroborated in this work (Hastenrath and Heller, 1977; Nobre and Shukla, 1996), i.e., advanced onset (demise) and delayed demise (onset) of the WES when southward (northward) low-level wind anomalies are observed on the Tropical Atlantic.

\subsection{Intraseasonal response on demise of the PWS}

In order to investigate possible relationship between the MJO activity and the demise of the PWS, we identified the occurrence of the MJO phase during each PWS event (Fig. 9). Since the persistence of the MJO in each phase is about 5-8 days, the results were then grouped into two consecutive phases (8-1, 2-3, 4-5 and 6-7 assigned to g1, g2, $\mathrm{g} 3$, and $\mathrm{g} 4$, respectively) in order to obtain a reasonably large sample. The Test of Difference in Proportions (Larry, 2006) was performed to estimate the statistical significance for each group of two MJO phases relative to the other groups. For example, the proportion of PWS events during phases 8-1 was tested against events during phases 2-3, 4-5 and 6-7. This criterion was based on similar pattern of geopotential height at 500-hPa over Northern South America from phase composites replicating the life cycle of the MJO (see Fig. 2 in Jones and Carvalho, 2012). In summary, just the proportion with MJO phases 4-5 is statistically different (5\% level for a two-tail test), as shown in the Table 1. The MJO was active during 20 demise cases out of 28 PWS events. Furthermore, 15 of those cases were assigned to phases $4-5.75 \%$ of all demise events of PWS during active MJO were identified in 4-5 MJO phases (Table 2). This result agrees with the positive geopotential height anomalies observed in the phase composites in Jones and Carvalho
(2012), it suggests that anomalous suppression of convection on intraseasonal timescales are found over Tropical South America sector during the demise events of the PWS.

Table 1 - Tests of proportion of groups with MJO phases (see text to reference). $Z$ values greater (less) than $1.96(-1.96)$ are statistically significant at $5 \%$. Positive (negative) value means that ordinates (abscissas) group has the highest proportion.

\begin{tabular}{lcccc}
\hline \multicolumn{5}{c}{ Z value } \\
\hline $\begin{array}{l}\text { Group test- } \\
\text { ing }\end{array}$ & $\mathrm{g} 1$ & $\mathrm{~g} 2$ & $\mathrm{~g} 3$ & $\mathrm{~g} 4$ \\
\hline $\mathrm{g} 1$ & - & -1.051 & -4.518 & 0 \\
$\mathrm{~g} 2$ & 1.051 & - & -3.815 & 1.052 \\
$\mathrm{~g} 3$ & 4.518 & 3.815 & - & 4.518 \\
$\mathrm{~g} 4$ & 0 & -1.051 & -4.518 & - \\
\hline
\end{tabular}

Table 2 - List of dates of demise of the PWS assigned by the group of the MJO life cycle what it occurs. g1, g2, g3, and g4 are labeled for the MJO phases 8-1, 2-3, 4-5, and 6-7, respectively.

\begin{tabular}{|c|c|c|c|c|}
\hline \multirow[b]{2}{*}{ Date } & \multicolumn{4}{|c|}{ Group of phases of the MJO life cycle } \\
\hline & g1 & g2 & g3 & g4 \\
\hline 21-Jan-80 & & & $\mathrm{X}$ & \\
\hline 5 -Feb-81 & & & $\mathrm{X}$ & \\
\hline $5-F e b-82$ & & & $\mathrm{X}$ & \\
\hline $20-F e b-83$ & & & $\mathrm{X}$ & \\
\hline 20-Feb-84 & & & $X$ & \\
\hline 11-Jan-86 & & & $\mathrm{X}$ & \\
\hline \multicolumn{5}{|l|}{ 20-Feb-87 } \\
\hline $5-F e b-88$ & & & $\mathrm{X}$ & \\
\hline 27-Dec-88 & $X$ & & & \\
\hline 1-Jan-90 & & $\mathrm{X}$ & & \\
\hline 25-Feb-91 & & & $\mathrm{X}$ & \\
\hline 31-Jan-92 & & $X$ & & \\
\hline \multicolumn{5}{|l|}{ 22-Dec-92 } \\
\hline \multicolumn{5}{|l|}{ 26-Jan-94 } \\
\hline 21-Jan-95 & & & $\mathrm{X}$ & \\
\hline 31-Jan-96 & & & $\mathrm{X}$ & \\
\hline 20-Feb-97 & & & $\mathrm{X}$ & \\
\hline \multicolumn{5}{|l|}{5 -Feb-98 } \\
\hline 5-Feb-99 & & & $\mathrm{X}$ & \\
\hline \multicolumn{5}{|l|}{ 26-Jan-00 } \\
\hline 27-Dec-00 & & $\mathrm{X}$ & & \\
\hline 31-Jan-02 & & & $X$ & \\
\hline \multicolumn{5}{|l|}{ 5-Apr-03 } \\
\hline 31-Jan-05 & & & $\mathrm{X}$ & \\
\hline \multicolumn{5}{|l|}{ 22-Dec-05 } \\
\hline 5 -Feb-08 & & & $\mathrm{X}$ & \\
\hline \multicolumn{5}{|l|}{ 7-Mar-09 } \\
\hline 31-Jan-10 & & & & $\mathrm{X}$ \\
\hline
\end{tabular}


The composite of $\mathrm{H} 200$ anomalies during the demise of the PWS along with 4-5 MJO phases shows a wave train over the South Pacific propagating from southern Australia towards South America (Fig. 10). Negative H200 anomalies over southern Brazil and South Atlantic suggest convergence and suppression signal of convection, which could lead a break conditions on summer precipitating systems (Carvalho et al., 2004; Jones and Carvalho, 2002). Similar results were found by Liebman et al. (1999), Jones and Carvalho (2002), and Carvalho et al. (2004). It is important to note that those previous studies used filtered submonthly (Liebmann et al., 1999) or intraseasonal data (Jones and Carvalho, 2002; Carvalho et al., 2004) to investigate the variability and active and break phases of the SAMS. The range of band-pass filtering is a priori arbitrary choice. This study analyzed departures from the annual cy- cle. The influence of the MJO (phase 4 and 5) on the demise of the PWS is clear in the upper tropospheric levels; similar analysis does not indicate significant circulation anomalies in the lower tropospheric levels over South America (not shown).

\section{Summary and Conclusions}

This study investigates interannual and intraseasonal changes on the onset/demise of the PWS and the WES over the NNB, focusing on their distinct characteristics and transition. The mean onset and demise of the PWS and WES found are December 12th/January 25th and February 09th/May 12th, respectively, which agree with previous studies (e.g. Raucher et al., 2005). The ENSO effect on anomalies of WES is remarkable, in El Nino (La Ninã/Neutral) events the onsets are delayed (anticipated) and de-

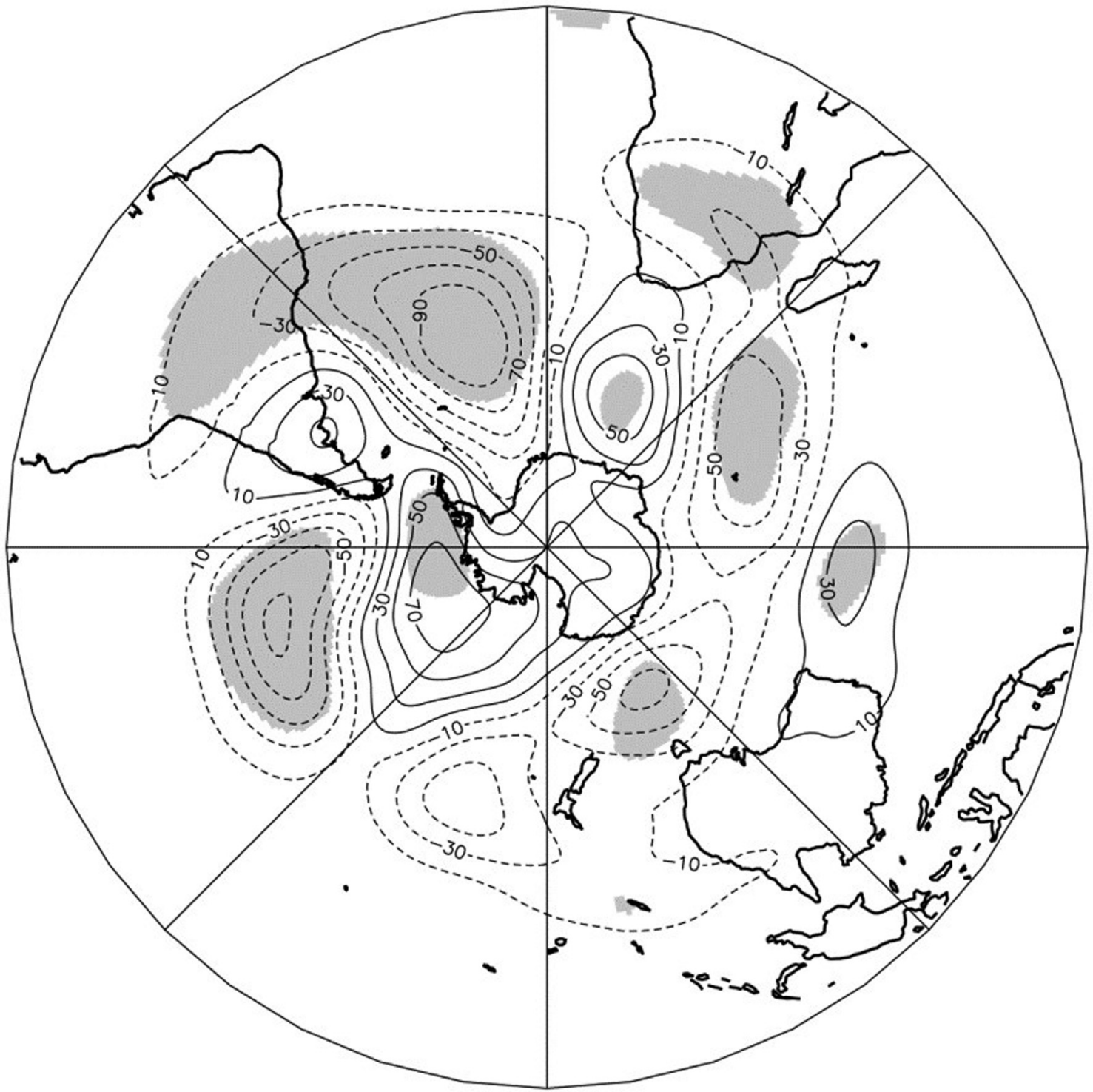

Figure 10 - Composite of $\mathrm{H} 200$ anomalies for demise events of the PWS marked by phase 4 or 5 (g3 group). Gray regions have statistical significance at $5 \%$ level. 
mises are anticipated (delayed), which is not clear for the onset/demise variability of the PWS. Differences between the PWS and WES features are noticeable; at the upper tropospheric levels, the Bolivian high and Northeast low (shifted to east) characterize the PWS along with the flow from Amazon Basin to South Brazil at lower levels characterize the PWS. These features are necessary to the development of an upper cyclonic vortex in vicinity of the NNB and provide conditions for the development the SACZ (Kousky and Gan, 1981; Lenters and Cook, 1997). During the WES, trade winds decrease in intensity because of southward displacement of ITCZ and upper anticyclone over South America weakens due to lack of heat source over land.

The lack of PWS in some years (1984/1985; 2003/2004 and 2006/2007) is explained by an anticyclonic anomaly over Southeastern South America during December/January; easterlies on center-western Brazil are also observed and indicate unfavorable conditions for vigorous development of the SAMS (Jones and Carvalho, 2002). It is reasonable, once that the main atmospheric system during the PWS is the Upper Tropospheric Cyclonic Vortex and agreed with the development of these systems over NNB and Tropical South Atlantic (Kousky and Gan, 1981). These results suggest a remote connection between the development of the PWS and the SAMS/SACZ, however further analysis still needed.

During ENSO warm phase convection is intensified convection over center-southern Brazil (Paegle and Mo, 2002) and that could contribute for development of the PWS, the anomalous subsidence generated over eastern Brazil by the change in Walker Circulation seems to be a factor that favors to early demise of the PWS (according to Alves et al., 1993). Cyclonic circulation anomalies over eastern South America along with easterlies on center-western Tropical Atlantic indicate favorable conditions to early onset of the PWS. Late onset of that period is marked by intense trade winds over Tropical South Atlantic and reversal wind anomaly over center Brazil. The changes on circulation at low levels during early (late) demise episodes of the PWS depict westerlies (easterlies) over Tropical Atlantic. Such information could improve the decision makers related to seed distribution and planting strategy during the PWS (Lemos et al., 2002).

The composites of circulation at low levels during early onset and late demise of the WES show north wind anomaly over Tropical Atlantic and displacement of South Atlantic subtropical high, respectively, while for late onset and early demise episodes south wind anomaly is observed.

The PWS is embedded in summer rainy systems over South America. In general, the transition from PWS to WES occurs within intraseasonal timescales, the demise of the PWS is marked by occurrence of the MJO phase 4-5 when the oscillation is active. The MJO influence takes place through Rossby waves which reach South America propagating over South Pacific Ocean from Oceania region. Similar signals had been found by other author but using filtered data (Liebmann et al., 1999). This feature is coherent with anomalous convection suppression over South America sector indicated at MJO phases 4-5 (Jones and Carvalho 2011), which highlights the importance to monitor and predict that intraseasonal oscillation over South America, and could improves the predictability of the timing of the rainy season (Bombardi et al., 2017).

Investigating the mechanisms associated with the PWS including its temporal variability can improve subseasonal forecasts for NNB once that provides information regarding timing variability and response from oceanic forcing. Further analyses are necessary to expand the understanding related to link between PWS and SAMS/SACZ development, for instance, correlate the onset/demise of the rainy season in the SAMS region with the onset/demise of the PWS.

\section{Acknowledgments}

We thank Dr. Brant Liebmann for providing daily precipitation data over the South America. GPCP data was provided by NOAA and reanalysis by ECMWF. The first author thanks the financial support of FAPESP, process numbers 2011/09314-2 and 2013/09642-5. C. Jones acknowledges the support from NOAA OGP (NA10OAR4310170).

\section{References}

ALVES, J., REPELLI, C.A., MELLO, N.S. A pré-estação Chuvosa do setor Norte e Nordeste brasileiro e sua relação com a temperatura dos oceanos adjacentes. Revista Brasileira de Meteorologia, v. 8, n. 1, p. 22-30, 1993.

ALVES, J.M.B., JACQUES, S., CAMPOS, J.N.B. Climate and rainfed agriculture in northeast Brazil. Plein textes La base de ressources documentaires de I'IRD. IRD. Publications des scientifiques de l'IRD. p. 249-270, 2010.

ANDREOLI, R.V., KAYANO, M.T. A Importância relativa do Atlântico tropical sul e Pacífico Leste na Varialibilidade da Precipitação do Nordeste do Brasil. Rev. Bras. Meteorol., v. 22, n. 1, p. 63-74, 2007.

BOMBARDI, R.J., CARVALHO, L.M.V. IPPC global coupled climate model simulations of the South America Monsoon System. Clim. Dyn., v. 33, n. 7-8, p. 893-916, 2009.

BOMBARDI, R.J., CARVALHO, L.M.V. The South Atlantic dipole and variations in the characteristics of the South American Monsoon in the WCRP-CMIP3 multi-model simulations. Clim. Dyn., v. 36, n. 11-12, p. 2091-2102, 2011

BOMBARDI, R.J., CARVALHO, L.M.V, JONES, C., REBOITA, M.S. Precipitation over Eastern South America and the South Atlantic Sea Surface Temperature during Neutral ENSO Periods. Climate Dynamics, v. 42, n. 5-6, p. 1553-1568, 2014.

BOMBARDI R.J, PEGION K.V, KINTER, J.L, CASH, B., ADAMS, J.M. Sub-seasonal Predictability of the Onset and Demise of the Rainy Season over Monsoonal Regions. Front. Earth Sci., v. 5, p. 14-27, 2017. 
BRITO, J.I.B., NOBRE, C.A. A precipitação da Pré-Estação e a previsibilidade da Estação Chuvosa no Norte do Nordeste. Climanalise, v. 6, p. 1-10, 1991.

CARVALHO, L.M.V., JONES, C., LIEBMANN, B. The South Atlantic convergence zone: Intensity, form, persistence, and relationships with intraseasonal to interannual activity and extreme rainfall. J. Clim., v. 17, n.1, p. 35-50, 2004.

CHAVES, R.R., CAVALCANTI, I.F.A. Atmospheric Circulation Features Associated with Rainfall Variability over Southern Northeast Brazil. Mon. Weather Rev., v. 129, p. 2614-2626, 2001.

CHIANG, J.C., VIMONT, D.J. Analogous Pacific and Atlantic Meridional Modes of Tropical Atmosphere-Ocean Variability. J. Clim., v.17, n. 21, p. 40-57, 2004.

COELHO, C.A., FIRPO, M.A., MAIA, A.H., MACLACHLAN, C. Exploring the feasibility of empirical, dynamical and combined probabilistic rainy season onset forecasts for São Paulo, Brazil. International Journal of Climatology, v. 37, n. S1, p. 398-411. 2017.

DEE, D.P., UPPALA, S.M., SIMMONS, A.J., BERRISFORD, P., POLI, P., KOBAYASHI, S., ANDRAE, U., BALMASEDA, M.A., BALSAMO, G., BAUER, D.P., BECHTOLD, P. The ERA-Interim reanalysis: Configuration and performance of the data assimilation system. Q. J. R. Meteorol. Soc., n. 137, n. 656, p. 553-597, 2011.

DURAND, B., SERVAIN, J., LAURENT, H., MACHADO, L.A.T. Tropical Atlantic Moisture Flux, Convection over Northeastern Brazil, and Pertinence of the PIRATA Network. J. Clim., v. 18, n. 12, p. 2093-2101, 2005.

GARCIA, S.R., KAYANO, M.T. Some evidence on the relationship between the South American monsoon and the Atlantic ITCZ. Theor. Appl. Climatol., v. 99, n. 1-2, p. 29-38, 2010.

GARCIA, S.R., KAYANO, M.T. Moisture and heat budgets associated with the South American monsoon system and the Atlantic ITCZ. Int. J. Climatol., v. 31, n. 14, p. 2154-2167, 2011.

HASTENRATH, S., HELLER, L. Dynamics of climatic hazards in northeast Brazil. Q. J. R. Meteorol. Soc., v. 103, n. 435, p. 77-92, 1977.

HASTENRATH, S., GREICHAR, L. Future Work the prediction of Northeast Brazil Rainfall Anomalies. J. Clim., v. 3, n. 8, p. 743-758, 1993.

JONES, C., CARVALHO, L.M.V. Active and break phases in the South American monsoon system. J. Clim., v. 15, n. 8, p. 905-914, 2002.

JONES, C., CARVALHO, L.M.V. Changes in the Activity of the Madden-Julian Oscillation during 1958-2004. J. Clim., v. 19, n. 24, p. 6353-6370, 2006.

JONES, C., CARVALHO, L.M.V. Spatial-Intensity Variations in Extreme Precipitation in the Contiguous United States and the Madden-Julian Oscillation. J. Clim., v. 25, n. 14, p. 4898-4913, 2012

JONES, C., WALISER, D.E., LAU, K., STERN, W., 2004: Global Occurrences of Extreme Precipitation and the Madden-Julian Oscillation: Observations and Predictability. J. Clim., v. 17, n. 23, p. 4575-4589, 2004.

KANE, R.P. El Niño and La Niña events and rainfall in NE and South Brazil. Rev. Bras. Geofis., v. 10, p. 49-59, 1992.

KANE, R.P. Prediction of droughts in north-east Brazil: role of ENSO and use of periodicities. Int. J. Climatol., v. 17, n. 6, p. 655-665, 1997.
KAYANO, M. T., ANDREOLI, R.V. 2004: Decadal variability of northern northeast Brazil rainfall and its relation to tropical sea surface temperature and global sea level pressure anomalies. J. Geophys. Res. Oceans 1978-2012, v. 109, n. C11, p. 1-8, 2004.

KOUSKY, V.E. Frontal Influences on Northeast Brazil. Mon. Weather Rev., v. 107, n. 9, p. 1140-1153, 1979.

KOUSKY, V.E. Pentad Outgoing Longwave Radiation Climatology for the South American Sector. Rev. Bras. Meteorol., v. 3, p. 217-231, 1988 .

KOUSKY, V.E., GAN, M. Upper tropospheric cyclonic vortices in the tropical South Atlantic. Tellus, v. 36, p. 538-551, 1981.

KOUSKY, V.E., KAYANO, M.T. Principal modes of outgoing longwave radiation and $250-\mathrm{mb}$ circulation for the South American sector. J. Clim., v. 7, n. 7, p. 1131-1143, 1994.

LARRY, J. S. Theory and Problems of Beginning Statistics. Schaum's Outline Series Second Edition, McGraw Hill, New York, p. 413, 2006.

LEMOS, M. C., FINAN, T.J., FOX, R.W., NELSON, D.R., TUCKER, J. The use of seasonal climate forecasting in policymaking: lessons from Northeast Brazil. Clim. Change, v. 55, n. 4 , p. 479-507, 2002.

LENTERS, J., COOK, K. On the origin of the Bolivian high and related circulation features of the South American climate. J. Atmospheric Sci., v. 54, n. 5, p. 656-678, 1997.

LIEBMAN, B., KILADIS, G.N., MARENGO, J.A., AMBRIZZI, T., GLICK, J.D. Submonthly convective variability over South America and the South Atlantic convergence zone. J. Clim., v. 12, n. 7, p. 1877-1891, 1999.

LIEBMAN, B., MARENGO, J.A. Interannual variability of the rainy season and rainfall in the Brazilian Amazon basin. $\mathbf{J}$. Clim., v. 14, n. 22, p. 4308-4318, 2001.

LIEBMAN, B., ALLURED, D. Daily precipitation grids for South America. Bull. Am. Meteorol. Soc., v. 86, n. 11, p. 1567-1570, 2005.

LIEBMAN, B., KILADIS, G.N., ALLURED, D., VERA, C.S., JONES, C., CARVALHO, L.M.V, BLADÉ, I., GONZÁLES, P. L. Mechanisms Associated with Large Daily Rainfall Events in Northeast Brazil. J. Clim., v. 24, n. 2, p. 376396, 2011.

MADDEN, R.A., JULIAN, P.R. Observations of the 40-50-day tropical oscillation-A review. Mon. Weather Rev., v. 122, n. 5, p. 814-837, 1994.

MOURA, A.D., SHUKLA, J. On the dynamics of droughts in northeast Brazil: Observations, theory and numerical experiments with a general circulation model. J. Atmospheric Sci., v. 38, n. 12, p. 2653-2675, 1981.

MOURA, A.D., HASTENRATH, S. Climate Prediction for Brazil's Nordeste: Performance of Empirical and Numerical Modeling Methods. J. Clim., v. 17, n. 13, p. 2667-2672, 2004.

NNAMCHI, H.C., LI, J., ANYADIKE, R.N. Does a dipole mode really exist in the South Atlantic Ocean? J. Geophys. Res. Atmospheres 1984-2012, v. 116, n. D15, p. 10-31, 2011.

NOBRE, P., SHUKLA, J. Variations of sea surface temperature, wind stress, and rainfall over the tropical Atlantic and South America. J. Clim., v. 9, n. 10, p. 2464-2479, 1996.

PAEGLE, J. N., MO, K.C. Linkages between summer rainfall variability over South America and sea surface temperature anomalies. J. Clim., v. 15, n. 12, p. 90-115, 2002. 
PAEGLE, J.N., BYERLE, L.A., MO, K.C. Intraseasonal modulation of South American summer precipitation. Mon. Weather Rev., v. 128, n. 3, p. 837-850, 2000.

RAUSCHER, S.A., SETH, A., LIEBMANN, B., QIAN, J.H., CAMARGO, S.J. Regional Climate Model-Simulated Timing and Character of Seasonal Rains in South America. Mon. Weather Rev., v. 135, n. 7, p. 2642-2657, 2007.

SARAVANAN, R., CHANG, P. Interaction between tropical Atlantic variability and El Nino-Southern Oscillation. J. Clim., v. 13, n. 13, p. 2177-2194, 2000.

RAIA, A., CAVALCANTI, I.F.A. The Life Cycle of the South American Monsoon System. J. Climate., v. 21, n. 23, p. 6227-6246, 2008.

SERVAIN, J. Simple climatic indices for the tropical Atlantic Ocean and some applications. J. Geophys. Res. Oceans 1978-2012, v. 96, n. C8, p 15137-15146, 1991.

SHIMIZU, M.H., AMBRIZZI, T., MJO influence on ENSO effects in precipitation and temperature over South America. Theoretical and Applied Climatology, v. 124, n. 1-2, p. 291-301, 2016.

SILVA, A.E., CARVALHO, L.M.V. Large-scale index for South America Monsoon (LISAM). Atmospheric Sci. Lett., v. 8, n. 2, p. 51-57, 2007.

SOUZA, E. B., AMBRIZZI, T. Modulation of the intraseasonal rainfall over tropical Brazil by the Madden-Julian oscillation. Int. J. Climatol., v. 26, n. 13, p. 1759-1776, 2006.

SUN, L., MONCUNILL, F.D., LI, H., MOURA, A.D. Climate downscaling over Nordeste, Brazil, using the NCEP RSM97. J. Clim., v. 18, n. 4, p. 551-567, 2005.

TASCHETTO, A., WAINER, I. The impact of the subtropical South Atlantic SST on South American precipitation. Annales Geophysicae, v. 26, n. 11, p. 3457-3476, 2008.
UVO, C., NOBRE, C.A. A zona de Convergência Intertropical (ZCIT) e a Precipitação no Norte do Nordeste do Brasil. Parte I: A posição da ZCIT no Atlântico Equatorial. Climanalise, n. 4, p. 39-48, 1989.

UVO, C., REPELLI, C., ZEBIAK, S., KUSHNIR, Y., The Relationships between Tropical Pacific and Atlantic SST and Northeast Brazil Monthly Precipitation. J. Clim., v. 11, n. 4, p. 551-562, 1998.

VALADÃO, C.E.A., LUCIO, P.S., CHAVES, R.R., CARVALHO, L.M.V. MJO Modulation of Station Rainfall in the Semiarid Seridó, Northeast Brazil. Atmospheric and Climate Sciences, v. 5, n. 4, p. 408-417, 2015.

VENEGAS, S., MYSAK, L., STRAUB, D.N. Atmosphere-ocean coupled variability in the South Atlantic. J. Clim., v. 10, n. 11, p. 2904-2920, 1997.

VENEGAS, S., MYSAK, L. STRAUB, D.N. Evidence for interannual and interdecadal climate variability in the South Atlantic. Geophys. Res. Lett., v. 23, n. 19, p. 2673-2676, 1996.

WHEELER, M.C., HENDON, H.H. An all-season real-time multivariate MJO index: Development of an index for monitoring and prediction. Mon. Weather Rev., v. 132, n. 8, p. 1917-1932, 2004.

XIE, P., JANOWIAK, J.E., ARKIN, P.A., ADLER, R., GRUBER, A., FERRARO, R., HUFFMAN, G.J., CURTIS, S. GPCP Pentad Precipitation Analyses: An Experimental Dataset Based on Gauge Observations and Satellite Estimates. J. Climate, v. 16, n. 13, p. 2197-2214, 2003.

ZHOU, J., LAU, K.M. Does a monsoon climate exist over South America? J. Clim., v. 11, n. 5, p. 1020-1040, 1998.

This is an Open Access article distributed under the terms of the Creative Commons Attribution Non-Commercial License which permits unrestricted non-commercial use, distribution, and reproduction in any medium provided the original work is properly cited. 